\title{
Corporate governance and business innovation among listed Moroccan companies
}

\author{
Zoubida Samlal \\ Système d'Information et d'Aide à la Décision, \\ Ecole Nationale de Commerce et de Gestion, Université Hassan-Ier, Settat, Morocco
}

\begin{abstract}
Purpose - This paper aims to clarify the relationship between corporate governance (GOV) and business innovation (INOV). Does it provide the empirical evidence of how different GOV mechanisms affect INOV within listed Moroccan companies?

Design/methodology/approach - The paper opted for a confirmatory quantitative study using a closedended questionnaire using a fifth-degree Likert scale. The questionnaire was administered to 54 listed Moroccan firms represented by their senior management having mainly a finance and economics background.

Findings - The paper provides empirical insights and evidence about how mechanisms of GOV impact INOV within listed Moroccan companies. It suggests that effective mechanisms of GOV foster and incubate INOV.

Research limitations/implications - There have been very empirical studies that investigate the relationship between GOV and innovation. As such, the authors' conceptual framework relies more on the theoretical aspect of this subject than empirical one. Therefore, researchers are encouraged to test the proposed propositions further.
\end{abstract}

Originality/value - A review of the few existing empirical studies shows mitigated results regarding the relation between $\mathrm{GOV}$ and innovation. The findings of this study show a significant positive relation between GOV and its mechanisms and INOV.

Keywords Innovation, Corporate governance, PLS, Institutional shareholders' services,

Business innovation, Moroccan equities listed companies

Paper type Research paper

\section{Introduction}

Over recent years, the topic of corporate governance (GOV) and its influence on innovation decisions has spiked the interest of researchers both at the theoretical and empirical levels. GOV is defined as the set of mechanisms that govern the behaviour of managers and align their decisions to the best interests of shareholders (Finet, 2009).

According to Jensen and Meckling (1976), GOV is inherently linked to innovation. Schumpeter (1934) defines innovation as the introduction of a new or significantly improved

(C) Zoubida Samlal. Published in Journal of Economics, Finance and Administrative Science. Published by Emerald Publishing Limited. This article is published under the Creative Commons Attribution (CC BY 4.0) license. Anyone may reproduce, distribute, translate and create derivative works of this article (for both commercial and non-commercial purposes), subject to full attribution to the original publication and authors. The full terms of this license may be seen at http://creativecommons.org/ licences/by/4.0/legalcode

The authors would like to extend sincere because of all the companies' executives who gave up their time to take part in this research and for answering the questionnaire. No funding were received for this study.

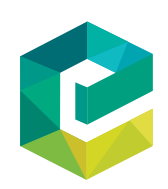

Journal of Economics, Finance and Administrative Science Vol. 25 No. 49, 2020 Vol. 25 No. 49,2020
pp. $61-72$ pp. $61-72$
Emerald Publishing Limited DOI 10.1108/JEFAS-05-2019-0074 
JEFAS

25,49

62

product or process, a new marketing method or a new organizational method in business practices, workplace organization or external relations.

From the theoretical perspective, the majority of cognitive governance scholars (Finet, 2009; Guéry-Stévenot, 2006; Charreaux and Wirtz, 2006) have firmly stated that GOV improves innovation, as it involves the adequate distribution of powers and decisionmaking across all management bodies of the firm. This led us to believe that a large number of empirical studies were able to prove a significant positive link between the two concepts.

Interestingly, the existing empirical works depict mitigated results and do not show a systematic linkage between GOV and innovation. Furthermore, most of these studies tackle the impact of some, and not all the factors, of GOV, namely, ownership structure and boards of directors on innovation (Chen, 2014; Jensen and Meckling, 1976). Many researchers (Chen, 2014; Tribo et al., 2007; Jensen and Meckling, 1976) explained that the mitigated results of these studies are attributed to a couple of reasons. The first reason referred to the complexity of variables involved, which made them challenging to measure. The second reason is the existence of different theoretical perspectives and assumptions that may explain the relationship between GOV and business innovation (INOV).

As a result, these authors argue that looking at simple direct relationships is not appropriate for fully understanding the influence of GOV on innovation. They recommended more sophisticated analyses that take into consideration the intricacies of GOV and its typology (Alegre-Vidal et al., 2004; Chen, 2014). As such, future empirical studies need to consider new conceptual models to better understand the relationship between GOV and innovation.

Thus, our present paper aims to take on this recommendation. We will attempt at first to propose a conceptual model that links different mechanisms of GOV to INOV. Then, we will test the proposed model and hypotheses in the context of listed Moroccan companies using the approach of the partial least squares model (PLS).

\section{The conceptual framework}

Our conceptual model will be presented through three steps process. First, we will present the theoretical review regarding GOV, INOV and the link between the two concepts. Second, we will discuss empirical evidence that tackles the nature of the relationship between the two notions. Finally, we will present our conceptual model and formulate our hypothesis.

\subsection{Theoretical review}

2.1.1 Corporate governance. There are several definitions of GOV. However, the most widely used one is given by the Organization for Economic Co-operation and Development (OECD), which states: GOV involves a set of relationships between company management, its board, its shareholders and other stakeholders. It also provides the structure through which the objectives of the company are set, and the means of attaining those objectives and monitoring performance are determined (Van de Ven, 1986). It appears interesting to cite the definition of Shleifer and Vishny (1997), who have given a financial perspective to GOV and state that: GOV deals with how suppliers of finance to corporations assure themselves of getting a return on their investment.

2.1.2 Business innovation. The concept of innovation comes from the Latin word "innovatus", which presages to change or renovate. In this sense, the concept of innovation can both designate the action of modifying what already exists or of creating and introducing something new within the company such as a product, a concept, a service or a process (Guéry-Stévenot, 2006; Charreaux, 1998). 
The Oslo Manual (1997) classifies INOV into four categories, namely, product innovation, process innovation, organization innovation and marketing innovation. This manual proposes the following definitions: product innovation is the introduction of a good or service, that is, new or significantly improved concerning its characteristics or intended uses. This includes significant improvements in technical specifications, components and materials, incorporated software, user-friendliness or other functional characteristics.

Process innovation is the implementation of a new or significantly improved production or delivery method. This includes significant changes in techniques, equipment and/or software. Organizational innovation is the implementation of a new organizational method in the firm's business practices, workplace organization or external relations. Marketing innovation is the implementation of a new marketing method involving significant changes in product design or packaging, product placement, product promotion or pricing.

2.1.3 The impact of corporate governance on business innovation. The notion of governance is derived from the act of "governess", which underpins two functions, namely, a "constraining" function, which is represented by the disciplinary paradigm of GOV and an "enabling" function to promote knowledge and competencies covered by the cognitive approach of governance (Alegre-Vidal et al., 2004; Zona et al., 2013).

Moreover, the cognitive paradigm of governance sees the firm as a repertory of knowledge and competencies. As such, mechanisms of GOV foster the ability of a company to accumulate knowledge and to develop distinct competencies and eventually to promote innovation (Alegre-Vidal et al., 2004).

The pioneering work of Jensen and Meckling (1976) was one of the first articles that link GOV mechanisms to innovation. These authors stated that the notion of GOV as a set of disciplinary mechanisms is inherently linked to innovation, as it involves the adequate distribution of powers and decision-making across all management bodies of the firm.

We can also cite the article of Lazonick and O'Sullivan. The two authors explained that for a company to innovate; it must be able to build new knowledge, and therefore, must engage in a collective and cumulative organizational learning process, which necessitates establishing a mechanism for adequate distribution of decision-making called GOV (Van Essen et al., 2012). To sum up, the scholars of GOV view this relationship from two perspectives. The first point of view sees innovation as the result of a good GOV system. This concept delivers to a firm the best potential for value creation by focussing on skills and innovation capabilities (Alegre-Vidal et al., 2004; Van Essen et al., 2012). The second one, supported by researchers like Lin et al. (2011), who view GOV as a prerequisite to installing a sound innovation ecosystem.

\subsection{The relationship between corporate governance and business innovation: empirical evidence}

Over recent years, interest has grown on the subject of the influence of GOV mechanisms on innovation. Several authors (Chizema and Kim, 2010; Tylecote and Visintin, 2007; Schumpeter, 1934; Chemmanur and Tian, 2017) state that innovation efforts depend mainly on how well mechanisms of GOV are implemented within organizations. These authors enumerate couple of mechanisms, namely, ownership structure and type of shareholder and the functioning of the board of directors. Interestingly, other mechanisms of GOV such as audit committee $(\mathrm{AC})$ or progressive practices $(\mathrm{PP})$ have not received the same interest from researcher sand have not been subject to empirical studies.

Moreover, these existing empirical studies have shown inconclusive findings and mitigated results. As a matter of illustration, we can cite the research of Chemmanur and Tian (2017), which shows that firms with anti-takeover provisions tend to innovate more. In 
JEFAS

25,49

contrast, the article by Sapra et al. (2014) shows a U-shaped relationship. According to these researchers, innovation occurs when there are very few or too many anti-takeover provisions. They stated that the convex link is because of the long-term process of innovation. According to these authors, a positive link is conditioned by setting up a longterm incentive package for executives.

Another interesting study is the work of Manso (2011), which analyses the impact of compensation mechanisms and senior management mandates on innovation. This author suggests that managers would be motivated to innovate if companies set up incentives such as long-term stock options, golden parachutes and other devices that encourage entrenchment.

As per the effect of the composition of the board of directors, authors such as Brunninge et al. (2007) and Shapiro et al. (2015) state that the independence of the board of directors has a positive effect on strategic changes and innovation. Other authors like Balsmeier et al. (2014) find rather mitigated results. As a matter of fact, theses authors find that independent directors with extensive experience who sit on the boards of high tech companies have a positive and significant impact on the number of applications for patents. However, they caution that the monitoring and advice of external directors does not always have a positive effect on research and development (R\&D) investment.

Furthermore, they indicate that the main role of the independent board members is to discipline strategic decisions rather than promoting R\&D activities. Understandably, the findings of these studies represent a novelty if we compared them to the existing literature. While theoreticians of GOV heralded the benefits of its mechanisms to promote innovation (Love, 2011; Jensen and Meckling, 1976; Hart, 1995; Wirtz, 2006) some of the recent empirical studies show the exact opposite (Hallara and Mrad, 2010; Bollaert et al., 2010).

To sum up, the review of the existing empirical studies shows not only mitigated results but also the lack of studies that explore the impact of other GOV mechanisms (except ownership structure and board independence) on INOV. As such, we aim by this study to examine the impact of the foremost common GOV mechanisms in the literature, namely, board of directors, AC, executive compensation and PP on INOV.

\subsection{Constructs identification and hypothesis' formulation}

In this section, we will discuss the constructs of the proposed model and the hypotheses formulation. Our conceptual model is composed of two constructs or variables. We identify our independent construct as GOV. The dependent construct is INOV.

2.3.1 Measures of the independent construct: corporate governance. According to Vo and Phan (2013), the existing relevant empirical studies about GOV have shown the predominance of four mechanisms, namely, board effectiveness, the independence of AC and compensation of executives and $\mathrm{PP}$ :

(1) Board effectiveness (BE): The BE refers to how well this latter performs its monitoring and strategic advisory roles such as governance and remuneration committees (Vo and Phan, 2013; Shapiro et al., 2015; Charreaux and Wirtz, 2006). Zona et al. (2013) argued that board characteristics such as composition and internal functioning are crucial to conceptualizing and determining BE based on the shareholder perspective.

(2) Vigilant audit committee: Some studies have found that companies with an AC, particularly when the committee is active and independent, have less chance for the occurrence of fraud and other irregularities in reporting (Vo and Phan,2013; Charreaux and Wirtz, 2006). Moreover, Love (2011) states that the AC should be 
permanent, independent and reporting directly to the board and having an advisory function with at least one member being independent and having expertise in accounting and/or auditing.

(3) Effective compensation of executives (CE): According to Affes (2011), the fundamental dilemma of GOV is the imperfect alignment of incentives between shareholders and managers, which can lead to behaviours and decisions by managers that are not in the interests of the firm's shareholders. This author refers to the pioneering work of Jensen and Meckling (1976) and states that when managers act in their personal interest at the expense of shareholders, it results in agency costs for the firm's owners, which reduces the value of shareholders. Several authors (Belloc, 2012; Vo and Phan, 2013; Shapiro et al., 2015) explain that shareholders can use managerial incentives to help align the manager's interests with those of shareholders.

(4) Progressive practices: According to the cognitive paradigm, GOV encourages managers to acquire specific competencies, and thus, implements new PP in their management style (Zona et al., 2013; Charreaux and Wirtz, 2006; Affes, 2011). Accordingly, these newly installed practices become explanatory factors for value creation and improving knowledge with the firm (Bollaert et al., 2010).

2.3.2 Measures of dependent construct: business innovation. The abundant literature of innovation tackles this concept on two levels as follows: studies that are explaining the dynamics of innovation within the industrial sector and those focussed on the innovation processes of services sectors (Guéry-Stévenot, 2006).

In the case of the industry sector, innovation is often perceived as a technological one measured by R\&D spending (Chen, 2014). Also, empirical studies of industrial firms offer a fairly wide range of factors that may influence the implementation of a technological innovation strategy such as firm size, degree of competition and public support for R\&D on innovation (Guéry-Stévenot, 2006; Chen, 2014; Tribo et al., 2007).

In contrast, studies of service-oriented firms recognize that innovation is usually nontechnological, and therefore, cannot be measured by R\&D activities (Tribo et al., 2007). These studies propose alternative indicators such as staff training, customer/supplier relationships.

Furthermore, the "community innovation surveys" of the Oslo Manual proposes a large panel of indicators describing the whole innovation process through three criteria, namely, the type innovation introduced the type of underlying innovative effort and the modalities of this effort (cooperation, public support, etc.). This manual recommends three key indicators, namely, R\&D activities, the number of patents and staff training (OECD, 1997).

Based on this review, we propose the following conceptual model as depicted in Figure 1.

2.3.3 Hypothesis formulation.

2.3.3.1 Effect of board effectiveness on innovation. According to the cognitive paradigm of GOV, the board of directors plays an enabling role through the creation and development of specific knowledge and incubation of innovation within the company (Lin et al., 2011; McConaughy et al., 1998; Shapiro et al., 2015; Zona et al., 2013). An effective board of directors plays a role in animating, training, mediating and coordinating exchanges among different parties of a firm. Consequently, it presents a stimulus improving competencies, knowledge and eventually innovation of a company (Zona et al., 2013). Therefore, we postulate the first hypothesis as:

H1. BE affects positively innovation within a firm. 
Figure 1.

The proposed model

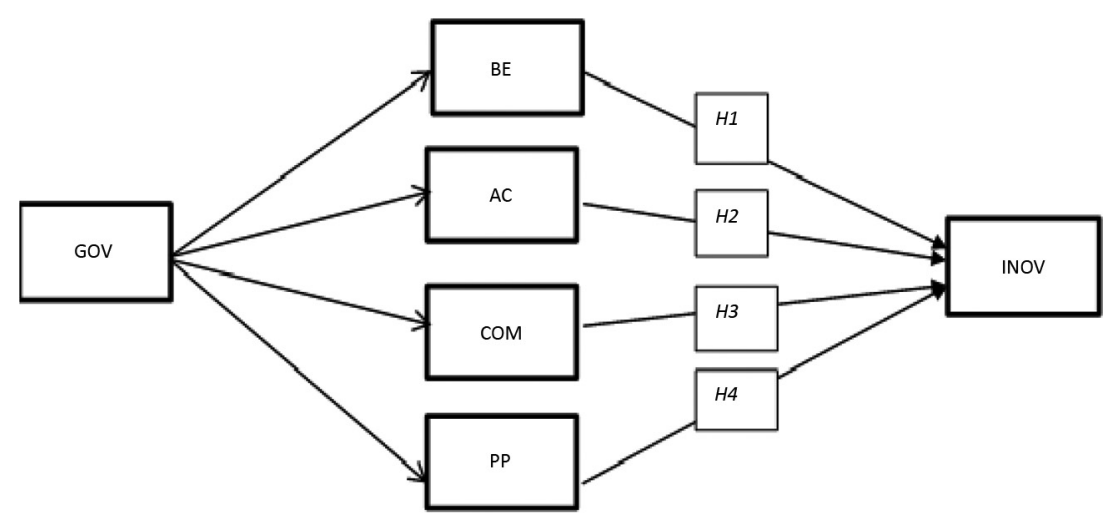

Source: Own elaboration

2.3.3.2 Effect of audit committee on innovation: lack of empirical studies. From a purely theoretical perspective, the effectiveness of GOV practices is deemed to incubate the innovation ecosystem within a company through effective cognitive channels of competencies and knowledge (McConaughy, 1998). This leads us to assume, that similarly to board effectiveness, the $\mathrm{AC}$ will promote innovation within a company. As such, and despite the lack of empirical studies, we postulate the second hypothesis:

H2. A vigilant $\mathrm{AC}$ affects positively innovation within a firm.

2.3.3.3 Effect of executive compensation on innovation. We have found a very limited number of studies that examine the link between executives' compensation on innovation. One of the very few is the research of Deutsch (2007) that examines the effects of outside directors' stock option compensation on R\&D intensity of 1,500 firms listed in the Standard and Poor's index between 1997 and 2000. This author suggests, based on the results of this study, to include stock options in executives' compensation in order to enhance firms' R\&D. Thus, we propose the third hypothesis:

H3. An effective executives' compensation affects positively innovation within a firm.

2.3.3.4 Effect of progressive practices on innovation. The study of Tsao and Chen (2012) explores the relationship between board-Chief Executive Officer (CEO) interactions and the performance of new product introduction of 198 industrial firms in Taiwan. This research identifies this link as curvilinear and depicts socio-political and socio-psychological forces that serve as an essential enabling context for managerial risk-taking. Furthermore, these authors acknowledge that practices derived from the board-CEO interactions soften managerial risk aversion and enable new product introduction to succeed (Lin et al., 2011; Tribo et al., 2007; Affes, 2011). As such, we can postulate the fourth hypothesis:

H4. PP affect positively innovation within a firm.

\section{Research methodology}

We opted for a confirmatory quantitative study. Our study consisted of a closed-ended questionnaire using the fifth-degree Likert scale. The questionnaire comprising 19 sections 
measuring five constructs introduced in our conceptual model, namely, the four mechanisms of GOV (board of directors, the AC, the compensation of executive and PP) and INOV. We would like to specify that we have underway in an earlier stage of this research a qualitative study that aimed to contextualize our conceptual model to the particularities of the Moroccan equities listed companies (Samlal and Jahidi, 2017).

Because of the limited number of equities listed companies in Morocco (73 firms), we used the convenience sampling technique to collect data. The questionnaire was administered to 54 listed Moroccan firms represented by their senior management. We questioned CEO, Chief

Operating Officers and Chief Financial Officers of the largest Moroccan firms listed in Casablanca stock exchange. Most of our panel has either a finance or an economics background. The questionnaire was administrated via Google form. We have studied the evolution of our selected sample over five years from 2012 to 2017. A total of 57 responses were obtained but three incomplete questionnaires were rejected. We report the data and characteristics of the 54 participants in Table I.

\section{Main findings}

The confirmatory analysis of our collected data are based on the structural equation model and more precisely the PLS. Our confirmatory approach to data analysis are of two steps. The first step is evaluating the measurement model, which is to check if the proposed conceptual model presents a good fit with the data collected. In other words, this test ensures that our constructs are well-identified in our conceptual model. The second step is the evaluation of the structural model, which aims to test our hypotheses.

\subsection{Measurement model}

The objective of this test is to ensure the measurement reliability of the proposed conceptual model and its constructs, which is done through two types of validities, namely, convergent validity and discriminant validity. Convergent validity refers to the degree to which two

\begin{tabular}{lrrrr}
\hline Characteristics & Participants & $(\%)$ & $\%$ valid & $\%$ accumulated \\
\hline Sector & 22 & 41 & 41 & 41 \\
Retail & 10 & 19 & 19 & 59 \\
Banking & 9 & 17 & 17 & 76 \\
Construction & 7 & 13 & 13 & 89 \\
Mining and energy & 6 & 11 & 11 & 100 \\
Telecom & 54 & 100 & 100 & \\
Total & & & & 52 \\
Capital structure & 28 & 52 & 52 & 85 \\
Institutional investors & 18 & 33 & 33 & 100 \\
International investors & 8 & 15 & 15 & \\
Private investors & 54 & 100 & & 56 \\
Total & & & & 100 \\
Position of the respondents & 30 & 56 & 56 & \\
CFO & 14 & 26 & 26 & \\
COO & 10 & 19 & 19 & \\
CEO & 54 & 100 & 100 & \\
Total & & & & Characteristics of the \\
Source: Own elaboration & & & & sample \\
\hline
\end{tabular}


JEFAS

25,49

68 measures of constructs that theoretically should be related, are related. It can be evaluated using three criteria as recommended by Fornell and Larcker (1981):

(1) loading greater than 0.50 ;

(2) composite reliability (CR) greater than 0.7 ; and

(3) the converging validity index (CVI) should exceed 0.5 .

In Table II, the results indicate that all constructs correspond to their respective items. All saturation coefficients are above the threshold of 0.50 . Cronbach's alpha values range from 0.74 to 0.925 and are above the threshold value of 0.7 . CR values are greater than 0.7 and the converging validity indices are all above the recommended level of 0.5 , indicating good internal consistency (Croutsche, 2002).

Discriminant validity tests whether concepts or measurements that are supposed to be unrelated are, in fact, unrelated. As per discriminant validity, the matrix of Fornell and Larcker depicts that the square root of the CVI, represented as the diagonal axis of the matrix, which should be superior to the off-diagonal correlation estimates (Chin and Newsted, 1999). All the constructs shows satisfactory discriminant validits test. Table III illustrates the sound discriminant validity of our constructs.

\subsection{Structural model}

The evaluation of the structural model ensures the robustness of the proposed conceptual framework, which is measured by three criteria (Chin and Newsted, 1999), namely, the quality of the structural equation $\left(Q^{2}\right)$, the nomological validity (Chin $\left.R^{2}\right)$ and the goodness to fit (GOF).

\begin{tabular}{|c|c|c|c|c|c|}
\hline Constructs & Items of measurement & Loading $>0.5$ & $\alpha$ of Cronbach's $>0.7$ & $\mathrm{CR}>0.7$ & $\mathrm{CVI}>0.5$ \\
\hline$B E$ & $\begin{array}{l}\text { GOV IND } \\
\text { RENU IND } \\
\text { MAND } \\
\text { SIZE }\end{array}$ & $\begin{array}{l}0.873 \\
0.834 \\
0.89 \\
0.889\end{array}$ & 0.925 & 0.944 & 0.771 \\
\hline$A C$ & $\begin{array}{l}\text { IND } \\
\text { TRANS }\end{array}$ & $\begin{array}{l}0.939 \\
0.943\end{array}$ & 0.872 & 0.94 & 0.886 \\
\hline$C E$ & $\begin{array}{l}\text { COMU } \\
\text { STC OPT }\end{array}$ & $\begin{array}{l}0.936 \\
0.933\end{array}$ & 0.883 & 0.944 & 0.894 \\
\hline$P P$ & $\begin{array}{l}\text { PERF } \\
\text { TRANS CONS }\end{array}$ & $\begin{array}{l}0.9 \\
0.937\end{array}$ & 0.817 & 0.915 & 0.844 \\
\hline INOV & $\begin{array}{l}\text { R\&D } \\
\text { PAT }\end{array}$ & $\begin{array}{l}0.882 \\
0.899\end{array}$ & 0.74 & 0.885 & 0.793 \\
\hline
\end{tabular}

Table II.

Convergent validity Source: Own elaboration

\begin{tabular}{llllll}
\hline Constructs & AUD & CA & COMP & INOV & PROG \\
\hline$C A$ & 0.941 & & & & \\
$B E$ & 0.762 & 0.878 & & & \\
$C E$ & 0.514 & 0.686 & 0.945 & & \\
$I N O V$ & 0.637 & 0.676 & 0.392 & 0.891 & 0.919 \\
$P P$ & 0.375 & 0.372 & 0.202 & 0.584 &
\end{tabular}

Table III.

Discriminant validity Source: Own elaboration 
The results obtained are satisfactory and depict the quality of the equation and the robustness of the model proposed. The $Q^{2}$ is above the threshold, which depicts the strong predictive ability of our model. The $R^{2}$ is superior to 0.1 , which proves the nomological validity of our model. The GOF is robust with a ratio of 0.86 , which is superior to the threshold of 0.3 (Table IV).

\subsection{Testing of research hypothesis}

In the final step, a structural equation analysis was conducted to estimate the causal relationships between the dimensions of the research model. The study of the significance of standardized regression coefficients, the $t$-values and $p$-value (Table V) led us to confirm all our hypotheses.

\section{Discussion and conclusion}

The effectiveness of the board of directors is viewed by the literature as the most important mechanism to install best practices of GOV (McConaughy et al., 1998). Its merits were subject to a large number of studies that confirm its positive effect on innovation (Lin et al., 2011; McConaughy et al., 1998; Shapiro et al., 2015; Zona et al., 2013).

The outcomes of this research converge with this statement. The path coefficient between the $\mathrm{BE}$ and INOV is the highest with a ratio of 0.373 . Thus, we were able to prove that an effective board leads to improve innovation in the context of Moroccan listed companies.

The vigilance of the $\mathrm{AC}$ is the second most discussed and studied the mechanism of GOV. Amid the lack of any previous empirical study that tackles or proves the positive link between a vigilant $\mathrm{AC}$ and innovation, we were able to prove in our study such a relationship. The path coefficient between the vigilance of the AC and INOV is 0.197 , which leads us to validate the second hypothesis.

The compensation of executives comes to solve the fundamental dilemma of GOV, which is the imperfect alignment of incentives between shareholders and managers (Tylecote and Visintin, 2007; McConaughy et al., 1998; Shapiro et al., 2015). Whilst the relationship

\begin{tabular}{lccc}
\hline Constructs & $Q^{2}>0$ & $R^{2}>0.1$ & GOF $>0.3$ \\
\hline$C A$ & 0.609 & 0.55 & 0.86 \\
$B E$ & 0.543 & 0.45 & \\
$C E$ & 0.502 & 0.46 & \\
$P P$ & 0.442 & 0.42 & \\
$I N O V$ & 0.326 & 0.382 &
\end{tabular}

Source: Own elaboration

Table IV. Validity of the structural model

\begin{tabular}{lcccc}
\hline Link & Original sample $(\mathrm{O})>0$ & $t$-statistics $>2.3$ & $p$-values $<0.05$ & Validity \\
\hline$B E \rightarrow I N O V$ & 0.373 & 12,880 & 0.000 & $H 1$ validated \\
$A C \rightarrow I N O V$ & 0.197 & 10,394 & 0.000 & $H 2$ validated \\
$C E \rightarrow I N O V$ & 0.155 & 8,359 & 0.000 & $H 3$ validated \\
$P P \rightarrow I N O V$ & 0.129 & 5,401 & 0.000 & $H 4$ validated
\end{tabular}

Source: Own elaboration

Table V.

Validity of research hypothesis 
JEFAS

25,49

between executives' compensation and firm performance has been extensively studied and proven, very few studies have been conducted to link this mechanism of governance to innovation (Tylecote and Visintin, 2007; Kwak, 2003). The outcomes of this study have empirically proven, in the context of Moroccan blue-chip companies, that an effective compensation scheme improves innovation within firms. The path coefficient derived from our hypothesis test depicts the strength and significance of this relationship. As such, the third hypothesis was validated.

The PP is the mechanism supported by the cognitive paradigm of GOV (Lin et al., 2011). According to Finet (2009), these practices urge the firm to adopt innovative approaches and to improve both the performance of the company's stock and its profitability (Tribo et al., 2007; Tylecote and Visintin, 2007). Our research has proven that PP yields to better innovation in the context of Moroccan companies. The fourth hypothesis was validated.

\section{Significance of this study}

The existing literature depicts a real shortage of empirical studies that propose new conceptual models taking into consideration the complexity of a construct such as GOV and positively ascertain the impact of this latter on INOV. Moreover, most of these studies tackle the impact of some, and not all the factors, of GOV. Thus, we believe that the significance of this work comes from the satisfactory and conclusive outcomes of our quantitative study.

To our knowledge, no empirical research was conducted to link AC or PP of GOV to INOV. Interestingly, we have proven through this study the positive correlation between all the four mechanisms of GOV, namely, the board of directors, AC, compensation of executive and PP and INOV. Moreover, we were able to test and validate our proposed conceptual model in the context of Moroccan listed companies.

\section{Constraints and limitations of this study}

In this study, we used rigorous data collection and analysis methods to promote the validity of the results. However, the results presented in this study were obtained from voluntary responses of respondents, which are discretionary to their judgements, perceptions and practices applied within their respective companies.

Our research was marked by a number of constraints. Because of a shortage of empirical studies tackling some mechanisms of GOV (namely, AC and PP) the proposed conceptual model relied solely on theoretical statements of researchers. Our quantitative study was constrained by the difficulty in establishing direct access with respondents, the limited size of our sample, the confidentiality and sensitivity of certain information and the time constraint.

\section{References}

Affes, H. (2011), "Indirect effect of leaders' incentive system type on financial performance through the level of innovation", Journal of Research in International Business and Management, Vol. 1 No. 4.

Alegre-Vidal, J., Lapiedra-Alcamí, R. and Chiva- Gomez, R. (2004), "Linking operations strategy and product innovation: an empirical study of Spanish ceramic tile producers", Research Policy, Vol. 33 No. 5, pp. 829-839.

Balsmeier, B., Buchwald, A. and Stiebale, J. (2014), "Outside directors on the board and innovative firm performance”, Research Policy, Vol. 43 No. 10, pp. 1800-1815.

Belloc, F. (2012), "Corporate governance and innovation: a survey", Journal of Economic Surveys, Vol. 26 No. 5, pp. 835-864. 
Bollaert, H., Daher, H., Derro, A. and Dupire-Declerk, M. (2010), "Corporate governance and performance of french listed companies”, IESEG School of Management, pp. 45-86.

Brunninge, O., Nordqvist, M. and Wiklund, J. (2007), "Corporate governance and strategic change in SMEs: the effects of ownership, board composition and top management teams", Small Business Economics, Vol. 29 No. 3, pp. 295-308.

Charreaux, G. (1998), "La théorie positive de l'agence: lecture et relectures", Centre de Recherche en Économie et Gestion Des Organisations, pp. 2-55.

Charreaux, G. and Wirtz, P. (2006), Gouvernance Des Entreprises: nouvelles Perspectives, Economica, Paris, France.

Chemmanur, T.J. and Tian, X. (2017), "Do anti-takeover provisions spur corporate innovation? A regression discontinuity analysis", 48.

Chen, H.L. (2014), "Board capital, CEO power and R\&D investment in electronics firms", Corporate Governance: An International Review, Vol. 22 No. 5, pp. 422-436.

Chin, W.W. and Newsted, P.R. (1999), "Structural equation modeling analysis with small samples using partial least squares", in Hoyle, R.H. (Ed.), Statistical Strategies for Small Sample Research, Sage Publications, Thousand Oaks, CA, pp. 307-341.

Chizema, A. and Kim, J. (2010), "Outside directors on Korean boards: governance and institutions", Journal of Management Studies, Vol. 47 No. 1, pp. 109-129.

Croutsche, J.J. (2002), "Étude des relations de causalité: utilisation des modèles d'équations structurelles (approche méthodologique)", La Revue des Sciences de Gestion Direction et Gestion.

Deutsch, Y. (2007), "The influence of outside directors' stock-option compensation on firms' R\&D”, Corporate Governance: An International Review, Vol. 15 No. 5, pp. 816-827.

Finet, A. (2009), Gouvernance D'entreprise: Nouveaux Défies Financiers et Non Financiers, Éditions De Boeck Université, Brussels, Belgium.

Fornell, C. and Larcker, D.F. (1981), "Evaluating structural equation models with unobservable variables and measurement error", Journal of Marketing Research, Vol. 18 No. 1, pp. 39-50.

Guéry-Stévenot, A. (2006), "Conflits entre investisseurs et dirigeants: une analyse en termes de gouvernance cognitive”, Revue Française de Gestion, Vol. 32 No. 164, pp. 157-180.

Hallara, S. and Mrad, M. (2010), "Privatization and performance: cognitive and behavioral governance, review and proposition of a new field of analysis", International Journal of Economics and Finance, Vol. 2 No. 3, pp. 46-58.

Hart, O. (1995), "Corporate governance: some theory and implications", The Economic Journal, Vol. 105 No. 430, pp. 678-689.

Jensen, M. and Meckling, W. (1976), "Theory of the firm: managerial behaviour, agency costs, and ownership structure", Journal of Financial Economics, Vol. 3 No. 4, pp. 305-360.

Kwak, M. (2003), “The advantages of family ownership”, MIT Sloan Management Review, Vol. 12.

Lin, P., Song, F.M. and Li, C. (2011), "Managerial incentives, CEO characteristics and corporate innovation in China's private sector", Journal of Comparative Economics, Vol. 39 No. 2, pp. 176-190.

Love, H. (2011), "Corporate governance and performance around the world: what we know and what we don't know”, The World Bank Research Observer, Vol. 261, pp. 42-70.

McConaughy, D.M., Walker, G., Henderson, H. and Mishra, C. (1998), "Founding family controlled firms: efficiency and value", Review of Financial Economics, Vol. 7 No. 1, pp. 1-19.

Manso, G. (2011), "Motivating innovation”, The Journal of Finance, Vol. 66 No. 5.

Samlal, Z. and Jahidi, R. (2017), "Compliance analysis of the best practices of corporate governance in Morocco: case of the large market capitalization companies", International Journal of Advanced Engineering, Management and Science. 
JEFAS 25,49

Sapra, H., Subramanian, A. and Subramanian, V. (2014), "Corporate governance and innovation: theory and evidence", Journal of Financial and Quantitative Analysis, Vol. 49 No. 4.

Schumpeter, J.A. (1934), The Theory of Economic Development: An Inquiry into Profits, Capital, Credit, Interest, and the Business Cycle, Harvard University Press, Cambridge.

Shapiro, D., Tang, Y., Wang, M. and Zhang, W. (2015), "The effects of corporate governance on innovation in Chinese firms", Journal of Chinese Economic and Business Studies, Vol. 13 No. 4.

Shleifer, A. and Vishny, R.W. (1997), "A survey of corporate governance”, The Journal of Finance, Vol. 52 No. 2, pp. 737-783.

Tribo, J., Berrone, P. and Surroca, J. (2007), "Do the type and number of blockholders influence R\&D investments? New evidence from Spain", Corporate Governance: An International Review, Vol. 15 No. 5 , pp. 828-842.

Tsao, S.M. and Chen, G.Z. (2012), "The impact of internationalization on performance and innovation: the moderating effects of ownership concentration", Asia Pacific Journal of Management, Vol. 29 No. 3, pp. 617-642.

Tylecote, A. and Visintin, F. (2007), Corporate Governance, Finance and the Technological Advantage of Nations, Routledge, Nueva York, New York, NY.

Van Essen, M., Van Oosterhout, J.H. and Carney, M. (2012), "Corporate boards and the performance of Asian firms: a meta-analysis", Asia Pacific Journal of Management, Vol. 29 No. 4, pp. 873-905.

Van de Ven, A.H. (1986), "Central problems in the management of innovation", Management Science, Vol. 32 No. 5, pp. 590-607.

Vo, D. and Phan, T. (2013), "Corporate governance and firm performance: empirical evidence from Vietnam", Economic Regulation Authority, pp. G32-G34.

Wirtz, P. (2006), "Compétences, conflits et création de valeur: vers une approche intégrée de la gouvernance”, Revue Finance Contrôle Stratégie, Vol. 9 No. 2, pp. 187-201.

Zona, F., Zattoni, A. and Minichilli, A. (2013), "A contingency model of boards of directors and firm innovation: the moderating role of firm size", British Journal of Management, Vol. 24 No. 3, pp. 299-315.

\section{Further reading}

OECD (1997), Oslo Manual: Proposed Guidelines for Collecting and Interpreting Technological Innovation, 2nd Ed., OECD Publishing, Paris.

Zhang, Q., Chen, L. and Feng, T. (2014), "Mediation or moderation? The role of R\&D investment in the relationship between corporate governance and firm performance: empirical evidence from the Chinese IT industry", Corporate Governance: An International Review, Vol. 22 No. 6, p. 501.

\section{Corresponding author}

Zoubida Samlal can be contacted at: samlalz@yahoo.fr

For instructions on how to order reprints of this article, please visit our website: 